\title{
Characterization and application of chars produced from pinewood pyrolysis and hydrothermal treatment
}

\author{
Zhengang Liu, Fu-Shen Zhang *, Jianzhi Wu \\ Research Center for Eco-Environmental Sciences, Chinese Academy of Sciences, 18 Shuangqing Road, Beijing 100085, China
}

\section{A R T I C L E I N F O}

\section{Article history:}

Received 16 June 2008

Received in revised form 16 August 2009

Accepted 25 August 2009

Available online 11 September 2009

\section{Keywords:}

Biomass

Adsorption

Oxygen-containing group

Heavy metal

Wastewater

\begin{abstract}
A B S T R A C T
Two types of pinewood chars, hydrothermal char (H300) and pyrolytic char (P700) from biomass-toenergy conversion were characterized and used as adsorbent for the copper removal from aqueous solution. The result showed that the pinewood underwent a deeper carbonization during pyrolysis process and more activated sites available and stable carbon-oxygen complex existed after hydrothermal treatment. Comparing with raw pinewood, hydrothermal treatment increased 95\% total oxygen-containing groups (carboxylic, lactone and phenolic group) while 56\% oxygen-containing groups decreased after pyrolysis process. SEM analysis indicated that both hydrothermal and pyrolytic processes developed rough surface with new cavities on the chars, and the BET surface area were 21 and $29 \mathrm{~m}^{2} / \mathrm{g}$ for H300 and P700, respectively. Although $\mathrm{H} 300$ had lower surface area, its adsorption capacity for copper was much higher than P700 since ion-exchange reaction was the predominant removal mechanism by H300, while physical adsorption dominated by P700. The adsorption data could be well described by Langmuir isotherm model for copper onto both H300 and P700.
\end{abstract}

(c) 2009 Elsevier Ltd. All rights reserved.

\section{Introduction}

There is a growing tendency nowadays for biofuel production using waste biomass because of the shortage of crude oil and environmental concern. The conversion from biomass to biofuel can be achieved through thermal and biological processes, and hydrothermal treatment and high-temperature pyrolysis are two major focuses in the thermal conversion [1-3]. Both thermal processes produce char as one of major products and with increasing importance on the biomass conversion, large amounts of chars from biofuel production will be produced in the near future. Some papers have been published about the characterization of chars from different biomass pyrolysis [4,5]. The chars from tobacco and pectin were studied and it was found that the physical and chemical characteristics of the chars were more dependent on treatment conditions than on nature of the substrates [6,7]. Chars obtained from pyrolysis of two hardwoods were characterized and the results showed that morphological features were strongly influenced by the operating conditions, especially temperature [8]. In the field of biofuel research, most attention has been paid to the liquid product and syngas but the char, which is also an attractive byproduct, has received less

\footnotetext{
* Corresponding author. Tel./fax: +86 1062849515.

E-mail address: fszhang@rcees.ac.cn (F.-S. Zhang).
}

attention. Thus far, there is not other value-added utilization available for this solid residue besides direct combustion for heat production.

Currently, adsorption is commonly regarded as the most excellent method for wastewater treatment, but the widespread utilization of this method is usually limited by technical and economical factors $[9,10]$. This calls for a research effort to develop effective and cheaper adsorbents to meet the demand. Under this situation, various kinds of adsorbents generated from agricultural and forest byproducts have been tested in order to evaluate their efficiencies in the removal of toxic metal ions and to develop a low cost and efficient process [11-15]. The fast thermal decomposition of biomass matrix resulted in complex surface structure and almost no extractable organic compounds left in the char. Considering these special characteristics, it is potentially more feasible to use chars as adsorbent in wastewater treatment.

To our best knowledge, there is no information related to the characterization and utilization of char produced from biomass hydrothermal conversion and, only limited reports on the application of chars from high-temperature pyrolysis [16-19]. In this study, pinewood was selected as a representative of waste biomass and two types of chars from pinewood thermochemical conversion processes were characterized and applied as adsorbents for copper removal from aqueous solution. The purpose of this preliminary research is to evaluate the feasibility of chars as adsorbent and to develop a value-added utilization for these byproducts. 


\section{Materials and methods}

\subsection{Char preparation}

The hydrothermal char used in this study was prepared using a typical hydrothermal treatment process [2]. Briefly, $5 \mathrm{~g}$ pinewood and $30 \mathrm{ml}$ deionized water were added into a $100 \mathrm{ml}$ stainless autoclave, and nitrogen gas was used to purge the air inside the reactor. The autoclave was heated to $300^{\circ} \mathrm{C}$ at a heating rate of $10^{\circ} \mathrm{C} / \mathrm{min}$. The reaction was held at $300^{\circ} \mathrm{C}$ for $20 \mathrm{~min}$ and then cooled down to room temperature. The solid product was extracted with acetone to produce bio-oil and char was recovered as solid residue (sample designed as $\mathrm{H} 300$ ).

For pyrolytic char preparation, a tubular reactor was employed. Typically, $5 \mathrm{~g}$ pinewood sample was heated from room temperature with a heating rate of $10^{\circ} \mathrm{C} / \mathrm{min}$. The inner atmosphere was nitrogen gas with a flow rate of $10 \mathrm{~cm}^{3} / \mathrm{min}$, and the sample was kept at $700{ }^{\circ} \mathrm{C}$ for $2 \mathrm{~h}$. The char was obtained as solid residue after the pyrolysis process (sample designed as P700).

The chars were washed several times using double-distilled water followed by drying in an oven at $105^{\circ} \mathrm{C}$ for $24 \mathrm{~h}$. Thereafter, the dried char samples were then ground to less than $0.5 \mathrm{~mm}$ and kept in a desiccator for use.

\subsection{Char characterization}

Elemental analysis of the chars were performed using a flash EA1112 Elemental Analyzer (USA). The BET surface area of the chars were measured using nitrogen as an adsorbate at $77 \mathrm{~K}$ in an automatic apparatus ASAP 2000 Micromeritics (USA). The Dubinin-Radushkevish method was used to determined the micropores volume of the chars and meso- and macropores volume was obtained using the Barrett-Joyner-Halenda method. The surface morphology was studied by SEM on S-3000N (Japan). FT-IR spectra were determined in the range of $400-4000 \mathrm{~cm}^{-1}$ using potassium bromide pelletization method on a Nicolet Nexus 670 spectrophotometer (USA). The amount of char and potassium bromide used in IR analysis were kept constant so as to compare the relative intensities of functional groups in different biochars. Copper concentration was analyzed by inductively coupled plasma optical emission spectroscopy OPTIMA 2000 (USA). Oxygen-containing functional groups (carboxylic, lactone and phenolic) were determined by Boehm titration method with different alkali solutions $(\mathrm{NaOH}$, $\mathrm{Na}_{2} \mathrm{CO}_{3}$ and $\mathrm{NaHCO}_{3}$ ). Briefly, a given amount of char was added to the alkali solutions ( $1 \mathrm{M}$ ) and the mixture was agitated at agitating bed for $24 \mathrm{~h}$. The supernatant was drawn and back titrated with $1 \mathrm{M} \mathrm{HCl}$ [20]. The $\mathrm{pH}$ measurements were made using a METTLER TOLEDO DELTA $320 \mathrm{pH}$ meter (Switzerland).

\subsection{Adsorption experiment}

Stock copper solution ( $1000 \mathrm{mg} / \mathrm{l})$ was prepared by dissolving $\mathrm{Cu}\left(\mathrm{NO}_{3}\right)_{2} \cdot 3 \mathrm{H}_{2} \mathrm{O}$ in $100 \mathrm{ml}$ double-distilled water. Different concentration solutions were prepared by diluting appropriate volume of stock solution and the $\mathrm{pH}$ value was adjusted by concentrated $\mathrm{HNO}_{3}$ or $\mathrm{NaOH}$ solutions. The amount of copper removal was
Table 2

Oxygen-containing functional groups in H300 and P700.

\begin{tabular}{lllll}
\hline Sample & \multicolumn{2}{l}{ Acidic surface functional group (meq/g) } & \multirow{2}{*}{ pH Value } \\
\cline { 2 - 3 } & $\begin{array}{l}\text { Carboxylic } \\
(-\mathrm{COOH})\end{array}$ & $\begin{array}{l}\text { Lactone } \\
(\mathrm{C}=\mathrm{O})\end{array}$ & $\begin{array}{l}\text { Phenolic } \\
(-\mathrm{OH})\end{array}$ & \\
\hline Raw pinewood & 0.10 & 0.16 & 0.17 & \\
H300 & 0.18 & 0.41 & 0.25 & 3.80 \\
P700 & 0.02 & 0.01 & 0.16 & 6.60 \\
\hline
\end{tabular}

determined by concentration difference in solutions before and after adsorption experiments.

\subsection{Quality assurance}

The data of given in present study were the average value of three-repeated runs for reliability. Analytical grade reagents and double-distilled water were used for adsorption experiments.

\section{Results and discussion}

\subsection{Chemical composition analysis}

Chemical composition of $\mathrm{H} 300, \mathrm{P} 700$ and the raw pinewood are shown in Table 1. As expected, the content of ash and carbon in H300 and P700 was much higher and the content of hydrogen and oxygen was much lower than the raw pinewood. The higher content hydrogen and oxygen in H300 indicated that more activated sites available and stable carbon-oxygen complex existed on the $\mathrm{H} 300$ surface than P700 [21]. The higher value of $\mathrm{C} / \mathrm{O}$ and $\mathrm{C} / \mathrm{H}$ in $\mathrm{P} 700$ than $\mathrm{H} 300$ indicated that pyrolysis at $700{ }^{\circ} \mathrm{C}$ underwent a deeper carbonization process than hydrothermal treatment at $300^{\circ} \mathrm{C}$. In comparison with P700, the lower ash content of $\mathrm{H} 300$ ascribed to the fact that most inorganic compounds contained in the wood dissolved in the water under hydrothermal conditions.

Table 2 shows the Boehm titration results for $\mathrm{H} 300$ and P700. As can be seen, total oxygen-containing functional groups was $0.84 \mathrm{meq} / \mathrm{g}$ for $\mathrm{H} 300$ which consist of $0.18,0.41$ and $0.25 \mathrm{meq} / \mathrm{g}$ for carboxylic, lactone and phenolic group, respectively. Total oxygen-containing functional groups for P700 were $0.19 \mathrm{meq} / \mathrm{g}$ with $0.02,0.01$ and $0.16 \mathrm{meq} / \mathrm{g}$ for carboxylic, lactone and phenolic group, respectively. Significant difference was observed for the content of lactone group in $\mathrm{H} 300$ and P700 (0.41 meq/g for H300 to $0.01 \mathrm{meq} / \mathrm{g}$ for P700). The total content of oxygen-containing groups in P700 decreased 77.39\% in comparison with H300, confirming a deeper carbonization process took place in P700. The $\mathrm{pH}$ values were 6.60 and 3.80 for P700 and H300, respectively. The lower $\mathrm{pH}$ value of $\mathrm{H} 300$ was consistent with the higher content of carboxylic group in $\mathrm{H} 300$.

Fig. 1 shows the infrared spectra of raw pinewood, H300 and P700. The FT-IR spectra of the two chars were different in shape and intensity, indicating that different thermal decomposition processes took place during hydrothermal treatment and pyrolysis. The significant absorption bands in the spectrum of H300 suggested that large amount of polar groups remained on the surface after hydrothermal treatment. Compared with the raw pinewood, the adsorption intensities of carboxylic group (bands at

Table 1

Ultimate and proximate analyzes of the raw pinewood and the chars.

\begin{tabular}{|c|c|c|c|c|c|c|c|}
\hline Sample & C (wt.\%) & H (wt.\%) & $\mathrm{N}(\mathrm{wt} . \%)$ & O (wt.\%) & Ash (wt.\%) & Volatile (wt.\%) & Fixed carbon (wt.\%) \\
\hline Pinewood & 49.25 & 6.18 & 0.30 & 44.17 & 0.30 & 78.86 & 14.25 \\
\hline H300 & 61.60 & 3.42 & 0.16 & 34.82 & 10.90 & 42.98 & 43.26 \\
\hline P700 & 95.30 & 0.82 & 0.12 & 3.76 & 38.83 & 3.20 & 57.05 \\
\hline
\end{tabular}




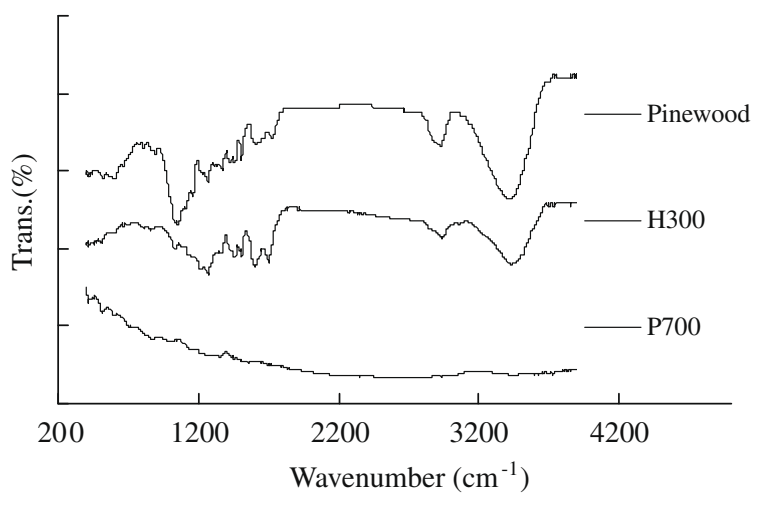

Fig. 1. FT-IR spectra of raw pinewood and chars.

$1600 \mathrm{~cm}^{-1}$ and $1460 \mathrm{~cm}^{-1}$ ) and carbonyl group (band at $1700 \mathrm{~cm}^{-1}$ ) were increased after hydrothermal treatment. While the content of $\mathrm{C}-\mathrm{O}$ bonds (bands between $1000 \mathrm{~cm}^{-1}$ and $1300 \mathrm{~cm}^{-1}$ ) and hydroxyl group (adsorption at $3430 \mathrm{~cm}^{-1}$ ) decreased. As for P700, the spectrum was quite flat indicating nearly all the polar functional groups including oxygen-containing groups have been decomposed during high-temperature pyrolysis. The above analysis was consistent with a previous reported that carboxylic and lactone groups decomposed in the range from $200{ }^{\circ} \mathrm{C}$ to $800^{\circ} \mathrm{C}$, phenol and ether group in the range from $500{ }^{\circ} \mathrm{C}$ to $1000^{\circ} \mathrm{C}$ [22]. The low polar group density on the surface denoted significant hydrophobic character of P700.

\subsection{Surface property analysis}

The surface property is important for char reactivity and the SEM images of the raw pinewood, H300 and P700 are shown in Fig. 2. It was noted that macropores were formed on the surface of P700, and H300 had coarser and rougher surface than P700. The smooth surface observed for P700 was developed by the melting and fusion process of the lignin and other small molecules

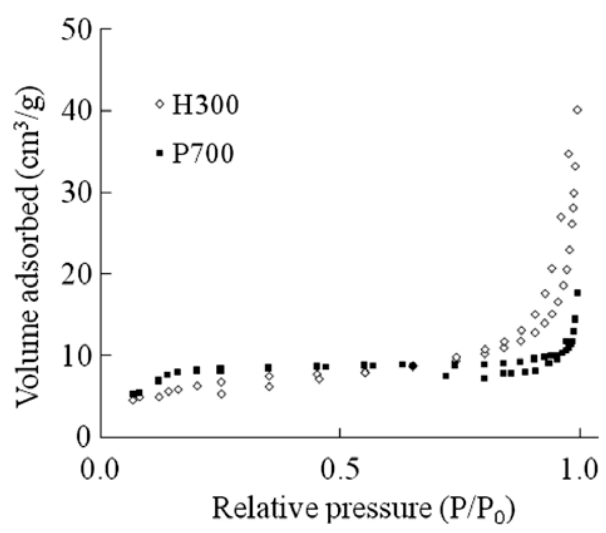

Fig. 3. Adsorption isotherm for $\mathrm{N}_{2}$ at $77 \mathrm{~K}$ for $\mathrm{H} 300$ and $\mathrm{P} 700$.

compounds in pinewood, such as pectin and inorganic compounds $[16,23]$. The vesicles on the smooth surface of P700 resulted from the release of volatile gas contained in the soften biomass matrix during the pyrolysis process [16]. The matrix became brittle and the collapses of part of vesicles were observed on the surface of P700. As for $\mathrm{H} 300$, the vesicles were formed through chemical bonds decomposition and fragmentation release from pinewood matrix taking into account the fact that hydrolysis reaction is predominant for biomass hydrothermal treatment.

The adsorption isotherms for $\mathrm{N}_{2}$ at $77 \mathrm{~K}$ for $\mathrm{H} 300$ and P700 are plotted in Fig. 3. From the shape of the isotherm, it may be stated that both chars belong to the Type IV according to IUPAC classification. The hysteresis loop observed in the isotherms was associated with capillary condensation taking place in the mesopores of chars. The BET surface areas were $21 \mathrm{~m}^{2} / \mathrm{g}$ for $\mathrm{H} 300$ and $29 \mathrm{~m}^{2} / \mathrm{g}$ for P700, respectively (Table 3 ). It has been reported that char surface area greatly depended on treatment temperature during biomass pyrolysis [19]. Thus the relatively low surface area of P700 accorded with previous reports that high temperature was unfavorable for the porous structure of the char $[7,8,21]$. Due to the high temperature and long residence time, the porous structure cracked
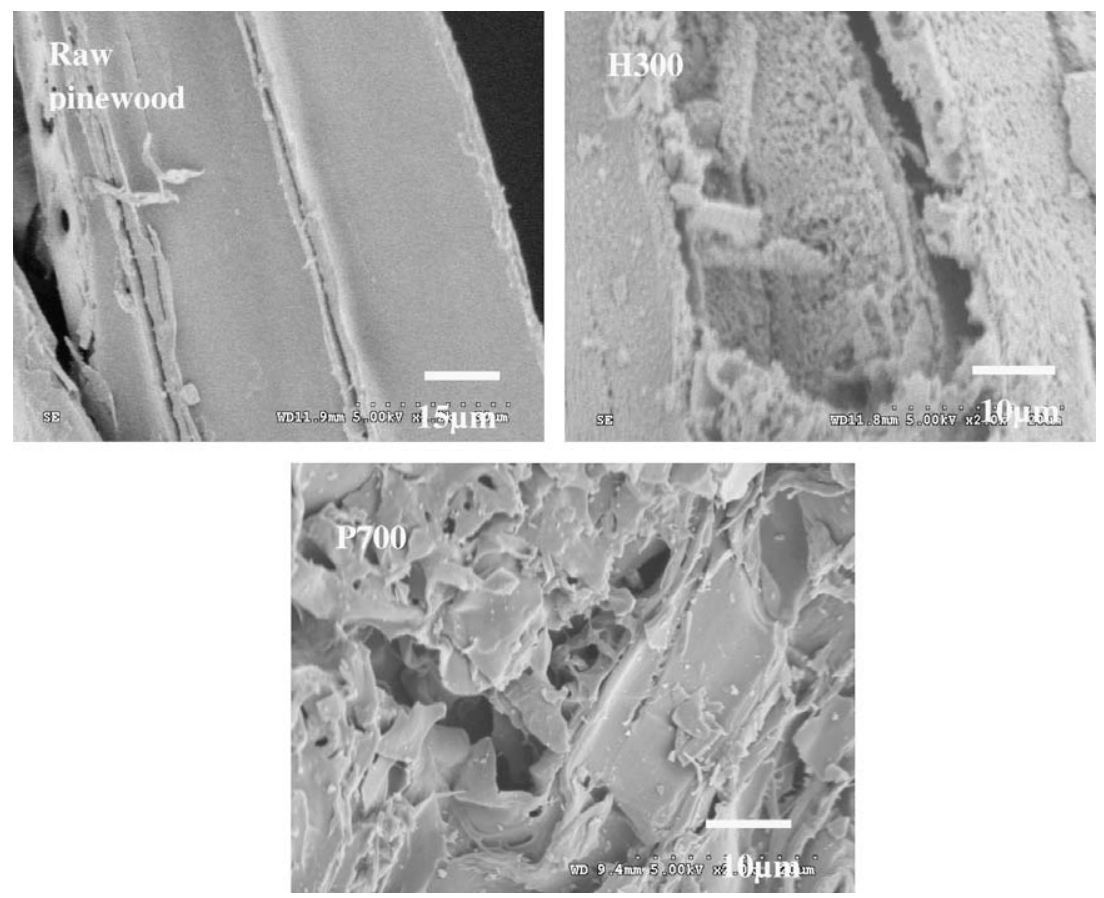

Fig. 2. SEM photographs of raw pinewood, H300 and P700. 
Table 3

Comparisons of surface structure of $\mathrm{H} 300$ and P700.

\begin{tabular}{lllll}
\hline Sample & $\begin{array}{l}\text { Surface } \\
\text { area }\left(\mathrm{m}^{2} / \mathrm{g}\right)\end{array}$ & $\begin{array}{l}\text { Average pore } \\
\text { diameter } \\
(\AA)\end{array}$ & $\begin{array}{l}\text { Micropore } \\
\text { volume } \\
\left(\mathrm{cm}^{3} / \mathrm{g}\right)\end{array}$ & $\begin{array}{l}\text { Meso- and } \\
\text { macropore } \\
\text { volume }\left(\mathrm{cm}^{3} / \mathrm{g}\right)\end{array}$ \\
\hline H300 & 21 & 8.6 & 0.09 & 0.05 \\
P700 & 29 & 14.8 & 0.13 & 0.89 \\
\hline
\end{tabular}

and the pores might be partially blocked as a result of the softening and melting of the pinewood constituents, which could lead to a low surface area [24].

\subsection{Adsorption studies}

The effects of $\mathrm{pH}$ on copper removal by $\mathrm{H} 300$ and P700 are shown in Fig. 4. Experiments were not carried out beyond pH 6.2 to avoid copper hydrolysis and precipitation. Generally, the removal rate of copper increased with increasing initial $\mathrm{pH}$ value ranging from 1.2 to 6.2 . It was found that the $\mathrm{pH}$ value has much more influence on $\mathrm{H} 300$ than P700, and the removal rate for H300 exhibited considerable increase from pH 3.2 to 4.2. These phenomena could be attributed to the change of the degree of ionization of oxygen-containing group on the adsorbent surface. At lower $\mathrm{pH}$, the surface oxygen linked to $\mathrm{H}^{+}$, making these inaccessible for copper. With increased $\mathrm{pH}$, the deprotonation of negative oxygen-containing group provided the chance to co-ordinate with copper, resulting in higher removal rate. Hence, the influence of $\mathrm{pH}$ on copper removal was caused by the competitive co-ordination between $\mathrm{H}^{+}$and $\mathrm{Cu}^{2+}$. Due to fewer amounts of oxygen-containing groups on P700 surface, less effect of pH on P700 was observed. The final $\mathrm{pH}$ value after adsorption was also measured and the result was shown in Fig. 5. It was observed that at $\mathrm{pH}<3.2$ the final $\mathrm{pH}$ value was almost equal to initial value while at $\mathrm{pH} \geqslant 3.2$, the initial $\mathrm{pH}$ were higher than final value and the deviation trend increased with the increasing initial $\mathrm{pH}$ value especially for $\mathrm{H} 300$. The deviation was caused by the release of $\mathrm{H}^{+}$form the chars to the solution and this result was agreed with previous reports $[22,25]$. To obtain the maximum copper removal rate, all the following experiments were carried out at initial pH 6.2.

The equilibrium adsorption data were fitted to Langmuir (Eq. (1)) and Freundlich (Eq. (2)) isotherms, which are two common functions for describing adsorption.

$\frac{C_{e}}{q_{e}}=\frac{1}{q_{\max } K_{L}}+\frac{C_{e}}{q_{\max }} \quad$ (Langmuir model $)$

$\ln q_{e}=\ln K_{F}+\frac{1}{n} \ln C_{e} \quad$ (Freundlich model)

where $q_{e}$ is the copper adsorbed per gram of char $(\mathrm{mg} / \mathrm{g})$ at equilibrium, $C_{e}$ the copper concentration in solution $(\mathrm{mg} / \mathrm{l})$ at equilibrium.

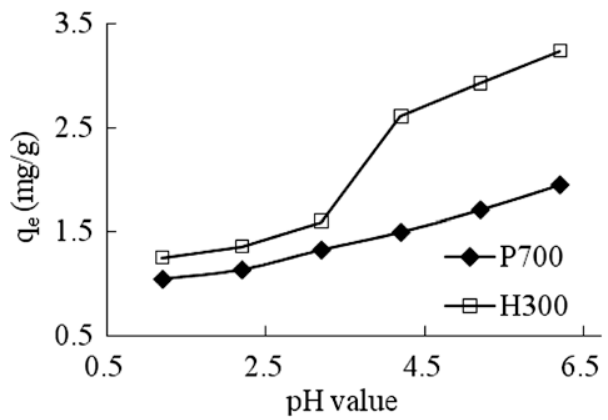

Fig. 4. Effect of pH on copper adsorption on $\mathrm{H} 300$ and $\mathrm{P} 700$.

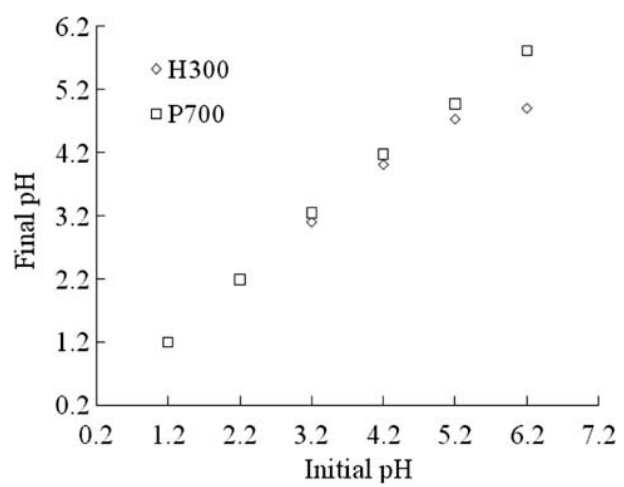

Fig. 5. The plot of initial $\mathrm{pH}$ against final $\mathrm{pH}$ value (copper concentration $10 \mathrm{mg} / \mathrm{g}$, adsorbent dose $2.5 \mathrm{~g} / \mathrm{l}$, temperature $25^{\circ} \mathrm{C}$ ).

Fig. 6 shows the plots of Langmuir and Freundlich adsorption isotherms of the copper on H300 and P700 and the adsorption coefficients are listed in Table 4. Based on the correction coefficients, the adsorption of copper on H300 and P700 were well described by Langmuir isotherm rather than Freundlich isotherm (correlation coefficient: $R^{2}>0.97$ and $R^{2}<0.90$ for Langmuir and Freundlich model, respectively). The worse fitness of Freundlich model could be attributed to the fact that the supply of adsorbent site was not infinite on the adsorbent surface. The Langmuir isotherm parameter $q_{\max }(\mathrm{mg} / \mathrm{g})$ indicated the maximum adsorption capacity of adsorbent and the value calculated from Langmuir equation was $4.46 \mathrm{mg} / \mathrm{g}$ for $\mathrm{H} 300$ and $2.75 \mathrm{mg} / \mathrm{g}$ for P700, respectively. Several studies have been conducted using various types of adsorbents for copper adsorption. Table 5 presents a comparison of the adsorption capacity of results. In spite of variety of parameters and conditions, direct comparison was impossible. However, as can be seen from the Table 5 that the adsorption capacity of copper onto the chars exceeded or was comparable to other adsorbents reported in literatures qualitatively, revealing that the chars was suitable for copper removal from aqueous solutions.

Due to different reactions took placed in the pinewood hydrothermal and pyrolytic treatment, two kinds of chars were obtained. The chars were utilized in copper removal from aqueous solutions and the adsorption mechanisms for $\mathrm{H} 300$ and $\mathrm{P} 700$ were proposed based on adsorption analysis and related literatures [31,32]. The main mechanism for $\mathrm{H} 300$ was ion-exchange reaction (exchange equal amount of charge $\left(\mathrm{H}^{+}\right.$and/or metal ions) to and from the solution), and physical surface adsorption for P700. Although fewer oxygen-containing groups on P700 surface, the maximum

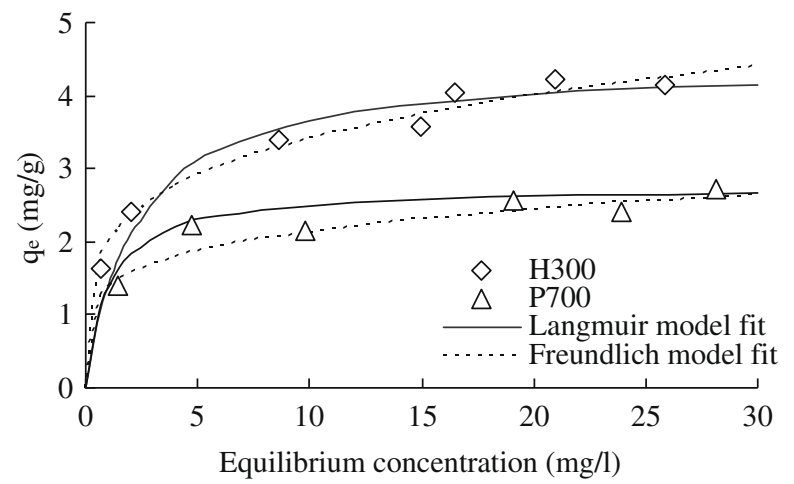

Fig. 6. Adsorption isotherms of copper by $\mathrm{H} 300$ and P700. Conditions: initial pH 6.2 , temperature $25^{\circ} \mathrm{C}$, adsorbent dose of $2.5 \mathrm{~g} / \mathrm{l}$. (-) Lines represent experimental data fitted by Langmuir model isotherm and $(-)$ lines represent the data fitted by Freundlich model isotherm. 
Table 4

Parameters of adsorption isotherms for Langmuir and Freundlich models.

\begin{tabular}{llll}
\hline Isotherm model & Parameters & \multicolumn{2}{l}{ Adsorbent } \\
\cline { 3 - 4 } & & H300 & P700 \\
\hline Langmuir & $K_{L}(\mathrm{l} / \mathrm{mg})$ & 0.46 & 1.00 \\
& $q_{\max }(\mathrm{mg} / \mathrm{g})$ & 4.46 & 2.75 \\
& $R^{2}$ & 0.97 & 0.97 \\
Freundlich & $K_{F}(\mathrm{mg} / \mathrm{g})$ & 2.00 & 1.38 \\
& $n$ & 4.32 & 5.24 \\
& $R^{2}$ & 0.88 & 0.85 \\
\hline
\end{tabular}

Table 5

Comparison of adsorption capacities of copper on other adsorbents.

\begin{tabular}{llll}
\hline Adsorbent & $\begin{array}{l}\text { Adsorption } \\
\text { capacity }(\mathrm{mg} / \mathrm{g})\end{array}$ & $\begin{array}{l}\text { Temperature } \\
\left({ }^{\circ} \mathrm{C}\right)\end{array}$ & References \\
\hline $\mathrm{H} 300$ & 4.21 & 25 & This study \\
P700 & 2.73 & 25 & This study \\
Sawdust carbon & 5.73 & 30 & {$[26]$} \\
$\mathrm{H}_{3} \mathrm{PO}_{4}$-activated rubber & 5.729 & 30 & {$[26]$} \\
$\quad \begin{array}{l}\text { wood sawdust } \\
\text { Rice hulls activated carbon }\end{array}$ & 6.64 & 18 & {$[27]$} \\
Turkish coal & 1.62 & 20 & {$[28]$} \\
Sawdust & 0.005 & 30 & {$[29]$} \\
Bagasse fly ash & 2.26 & 30 & {$[30]$} \\
\hline
\end{tabular}

adsorption capacity, $2.75 \mathrm{mg} / \mathrm{g}$, can be obtained due to higher surface area for adsorption.

\section{Conclusions}

The preliminary study has shown that a thorough carbonization process take place in P700 and nearly all the oxygen-containing groups decompose during pyrolysis process. Contrary to the pyrolysis process, the hydrothermal treatment creates much more oxygen-containing groups on the char's surface. Both hydrothermal treatment and pyrolysis could develop rough surface and porous structure through different reactions. Copper removal from wastewater by $\mathrm{H} 300$ is mainly through ion-exchange mechanism while physical surface adsorption for P700. The adsorption data could be well described by Langmuir model and the maximum adsorption capacities are 4.46 and $2.75 \mathrm{mg} / \mathrm{g}$ onto $\mathrm{H} 300$ and P700, respectively. Through comparison with other adsorbent, these byproduct chars from biomass-to-energy conversion, especially hydrothermal char, can be used as effective adsorbent for copper removal form wastewater.

\section{Acknowledgement}

This work was financially supported, in part, by the National Basic Research Program of China (2007CB407303).

\section{References}

[1] Liu A, Park Y, Huang Z, Wang B, Ankumah RO, Biswas PK. Product identification and distribution from hydrothermal conversion of walnut shells. Energy Fuels 2006;20:446-54.

[2] Karagoz S, Bhaskar T, Muto A, Sakata Y. Comparative studies of oil compositions produced from sawdust, rice husk, lignin and cellulose by hydrothermal treatment. Fuel 2005;84:875-84.
[3] Mohan D, Pittman CU, Steele PH. Pyrolysis of Wood/Biomass for Bio-oil: A Critical Review. Energy Fuels 2006;20:848-89.

[4] Zanzi R, Sjostrom K, Bjornbom E. Rapid high-temperature pyrolysis of biomass in a free-fall reactor. Fuel 1996;75:545-50.

[5] Biagini E, Narducci P, Tognotti L. Size and structural characterization of lignincellulosic fuels after the rapid devolatilization. Fuel 2008;87:177-86.

[6] Sharma RK, Wooten JB, Baliga VL, Smith PA, Hajilogol MR. Characterization of char from the pyrolysis of tobacco. J Agric Food Chem 2002;50:771-83.

[7] Sharma RK, Nacten JB, Baliga VL, Smith PA, Hajilogol MR. Characterization of chars from biomass-derived materials: pectin chars. Fuel 2001;80:1825-36.

[8] Della Rocca PA, Cerrella EG, Bonelli PR, Cukierman AL. Pyrolysis of hardwoods residues: on kinetics and chars characterization. Biomass Bioenergy 1999; $16: 79-88$

[9] Wilderer PA, Bungartz H-J, Lemmer H, Wagner M, Keller J, Wuertz S. Singleand multi-component adsorption of cadmium and zinc using activated carbon derived from bagasse-an agricultural waste. Water Res 2002;36:370-93.

[10] Cheremisinoff NP. An overview of water and waste-water treatment, handbook of water and wastewater treatment technologies. Woburn: Butterworth-Heinemann; 2002. 1-61.

[11] Larsen VJ, Schierup H. The use of straw for removal of heavy metals from waste water. J Environ Qual 1981;10:188-93.

[12] Al-Asheh S, Duvnjak Z. Sorption of cadmium and other heavy metals by pine bark. J Hazard Mater 1997;56:35-51.

[13] Gaballah I, Kilbertus G. Recovery of heavy metal ions through decontamination of synthetic solutions and industrial effluents using modified barks. J Geochem Explor 1998;62:241-86.

[14] Costa ETH, Winkler-Hechenleitner AA, oacute EA, mez-Pineda. Removal of cupric ions from aqueous solutions by contact with corncobs. Sep Sci Technol 1995;30:2593-602.

[15] Shukla SR, Sakhardande VD. Removal of metal ions using dyed cellulosic materials. Dyes Pigments 1991;17:101-12.

[16] Sharma RK, Wooten JB, Baliga VL, Lin X, Geoffrey Chan W, Hajaligol MR Characterization of chars from pyrolysis of lignin. Fuel 2004;83:1469-82.

[17] Biagini E, Narducci P, Tognotti L. Size and structural characterization of lignincellulosic fuels after the rapid devolatilization. Fuel 2008;87:177-86.

[18] Rocca PAD, Cerrella EG, Bonelli PR, Cukierman AL. Pyrolysis of hardwoods residues: on kinetics and chars characterization. Biomass Bioenergy 1999;16:79-88.

[19] Sharma RK, Wooten JB, Baliga VL, Martoglio-Smith PA, Hajaligol MR Characterization of char from the pyrolysis of tobacco. J Agric Food Chem 2002;50:771-83.

[20] Boehm HP. Chemical identification of surface groups. In: Eley DD, Pines $\mathrm{H}$, Weisz PB, editors. Advances in catalysis, vol. 16. New York: Academic Press; 1966. p. 179.

[21] Guerrero M, Ruiz MP, Alzueta MU, Bilbao R, Millera A. Pyrolysis of eucalyptus at different heating rates: studies of char characterization and oxidative reactivity. J Anal Appl Pyrol 2005;74:307-14.

[22] Mohan D, Pittman CU, Bricka M, Smith F, Yancey B, Mohammad J, et al Sorption of arsenic, cadmium, and lead by chars produced from fast pyrolysis of wood and bark during bio-oil production. J Colloid Interface Sci 2007;310:57-73.

[23] Cetin E, Moghtaderi B, Gupta R, Wall TF. Influence of pyrolysis conditions on the structure and gasification reactivity of biomass chars. Fuel 2004;83:2139-50.

[24] Sharma RK, Wooten JB, Baliga VL, Martoglio-Smith A, Hajaligol MR. Characterization of char from the pyrolysis of tobacco. J Agric Food Chem 2002;50:771-83.

[25] Kadirvelu K, Faur-Brasquet C, Cloirec PL. Removal of $\mathrm{Cu}(\mathrm{II}), \mathrm{Pb}(\mathrm{II})$, and $\mathrm{Ni}(\mathrm{II})$ by adsorption onto activated carbon cloths. Langmuir 2000;16:8404-9.

[26] Kalavathy MH, Karthikeyan T, Rajgopal S, Miranda LR. Kinetic and isotherm studies of $\mathrm{Cu}(\mathrm{II})$ adsorption onto $\mathrm{H}_{3} \mathrm{PO}_{4}$-activated rubberwood sawdust. J Colloid Interface Sci 2005;292:354-62.

[27] Imamoglu M, Tekir O. Removal of copper (II) and lead (II) ions from aqueous solutions by adsorption on activated carbon from a new precursor hazelnut husks. Desalination 2008;228:108-13.

[28] Karabulut S, Karabakan A, Denizli A, Yurum Y. Batch removal of copper(II) and zinc(II) from aqueous solutions with low-rank Turkish coals. Sep Purif Technol 2000;18:177-84.

[29] Ajmal M, Khan AH, Ahmad S, Ahmad A. Role of sawdust in the removal of copper (II) from industrial wastes. Water Res 1998;32:3085-91.

[30] Gupta VK, Ali I. Utilization of bagasse fly ash (a sugar industry waste) for the removal of copper and zinc from wastewater. Sep Purif Technol 2000;18:131-40.

[31] Reddad Z, Gerente C, Andres Y, Le Cloirec P. Adsorption of several metal ions onto a low-cost biosorbent: kinetic and equilibrium studies. Environ Sci Technol 2002;36:2067-73.

[32] Sciban M, Radetic B, Kevresan Z, Klasnja M. Adsorption of heavy metals from electroplating wastewater by wood sawdust. Bioresour Technol 2007;98:402-9. 